\title{
The effects of using social biographical texts of scientists on students' attitudes in science courses: A qualitative study
}

\author{
Riza Salar and Ayhan Aksakalli \\ Atatürk University, Turkey
}

Biographies of scientists are often used in the teaching environment, both in textbooks and in course contents - sections from the lives of scientists are often included to encourage students to pursue and enjoy science. This research investigated the effect of social content biographical texts of scientists on students' attitudes towards science courses. The research was a mixed-method study and consisted of 51 science teachers. The participants were determined according to a convenience sampling method. Focus group interviews, repertory grid technique, and individual interviews were used to collect data in the study. Through focus group interviews with teachers, it was discussed what kind of changes biographical texts might make to students' attitudes to science. Later, 51 teachers explained the social biographical texts to their students and observed the changes in the students. Based on their observations, they scored the repertory grids. Finally, an individual interview was held with fifteen teachers. As a result, it has been determined that social biographical texts were able to increase students' interest, motivation and

\section{ARTICLE DETAILS}

LUMAT General Issue Vol 9 No 1 (2021), 570-596

Received 7 March 2021

Accepted 10 August 2021

Published 11 August 2021

Pages: 27

References: 76

Correspondence: rizasalar@atauni.edu.tr

https://doi.org/10.31129/ LUMAT.9.1.1560 questioning skills, while able to decrease their anxiety.

Keywords: social content biographical texts, science, scientists, attitudes

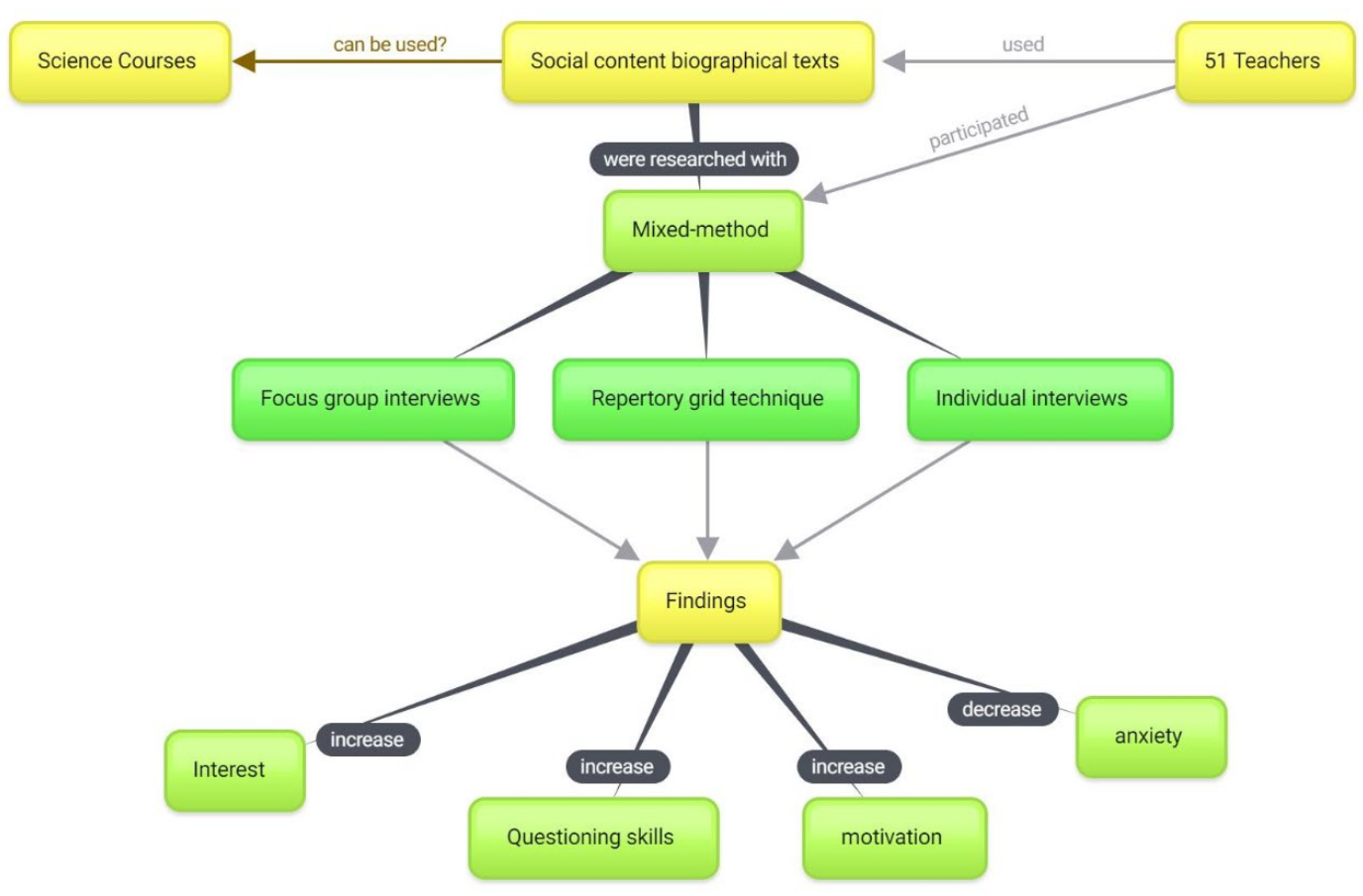


Crises in science education are widely accepted, and the low rate of science literacy emerges as a troubling situation. Is it right to accept this dire result and wait for this to change without doing anything? Evolving reality has shown that science is the greatest culture that human beings take refuge in (Davies \& Davies, 1984). The culture of science, which has an interesting and complex past, has brought to light a lot of information about ourselves and about the world we live in. The departure of teachers and students from this science culture, which directly and indirectly transforms both the social and natural worlds, has manifested itself as a dramatic situation (Hodson, 2008; Matthews, 1991). For example, in the mid-1980s, 600 people chose science programs every year in the USA, and 8000 people left this profession - this is compelling evidence of the moving from science classes by teachers and students (Mayer, 1987). Bown (1993) argues that students move away from science and even if these students enter university to study science, their level is very low.

There are complex economic, social, and cultural reasons for students 'distancing' themselves from science. Teachers alone are not able to solve all economic, social, and cultural problems. But at the very least, if they convey the relationship between scientists and achievement objectively, without relying too much on classical ideas, they can help correct the necessary curriculum and pedagogical deficiencies in science by breaking the prejudices that to be successful one must be born gifted (Matthews, 1992). As Lin-Siegler, Ahn, and Chen (2016) said, the mind can be improved, and this can be achieved by new experiences, not just by talent. This is of course not easy, but it is very useful to teach the techniques that achievers use to overcome difficulties and learn.

One-sided approaches to the lives of scientists when dealing with science in schools are important when understanding the perspectives of students who feel that they are 'against' science. The irrational views put forward about what people must do to become scientists are so embedded in today's curriculum that they believe that the only way for students to be successful in science is to have a solid innate intelligence (Hong \& Lin-Siegler, 2012; Martin \& Brouwer, 1993). Popular versions of postmodernism and constructivism in the field of education, unfortunately, reduce students' interest in science and divert their interest in other directions. Since they think that other students' successes in science are based on extraordinary abilities, their motivation towards science decreases (Lin-Siegler et al., 2016) and they consider their success as idealism and dreaminess (Matthews, 1991). 
In their research, Lin-Siegler et al. (2016) asked the students whether they thought they could become scientists or not. They found that the students had difficulty even in imagining their roles in this field, and encountered answers like, "I have never thought about this before, and I cannot say that I am good at this anyway." The research also pointed to the disconnection between students' comments about themselves and scientists, as they had participant judgments that being successful in science was only possible with talent.

This situation has resulted in students who think that innate abilities are necessary for efforts requiring high-level scientific performance, giving up without giving themselves a chance (Bandura, 1977, 1986; Dweck, 2000; Hong \& Siegler, 2012). The belief in innate talent leads to the emergence of false beliefs that they will never be successful in science, even with a lot of work from the students (Dweck, 2010, 2012; Hong \& Siegler, 2012). The most unexpected consequence of these false beliefs is that students' desire to pursue a career in science and technology is dulled (National Academy of Science, 2005). Worst of all, it changes students' attitudes towards science in a negative way, as well as being a serious factor that keeps them away from science and mathematics courses in high school and university (Blickenstaff, 2005; Singh, Granville, \& Dika, 2002; Wang, 2013). It can be said that the perception of being successful only with innate talents is not only about students themselves, but also teachers, textbooks, and the media are effective in the emergence and persistence of this belief (Chambers, 1983; Farland, 2006; Finson, 2002; Schibeci \& Sorensen, 1983).

In lessons, teachers talk about scientists' abilities and achievements rather than problems in their social lives, which reduce the motivation of students who fail in science (Shumow \& Schmidt, 2014). The positive development of attitudes towards science depends not only on the special talents of scientists, but also on the feeling of not giving up despite the difficulties they experience in their social life. In this sense, one of the ways to be successful in science depends on the ability to face obstacles in a social life and to use the skills of not giving up despite everything. In this respect, especially in schools, not only should the talents of scientists but also biographies showing how they coped with the difficulties in their social lives be included (LinSiegler et al., 2016).

In this study, it was aimed to investigate the effects of social biographical texts on students' attitudes according to science teachers. The use of biographical texts in the classrooms depends on teachers' attitudes towards them. Therefore, these findings 
can contribute to science education literature. In this study, answers to the following questions were sought:

1. According to science teachers, which attitudes of students can be affected by social biographical texts?

2. How do science teachers evaluate the change in students' attitudes when social biographical texts are taught?

3. What are the opinions of teachers who argue that social biographical texts will cause changes in students' attitudes about biographical texts?

\section{Theoretical framework}

\subsection{Biographical texts}

Biography, also known as resume and life history, is a literary genre that reveals the lives and actions of important people based on documents (Oğuzkan, 2001). In other words, a biography is a document that presents the lives of people who have come to the forefront with their work and behaviour, and who have achieved significant success in fields such as science, art, literature, politics, and sports with a neutral eye (Kaymakçı \& Er, 2009). On the other hand, a biography in terms of educational sciences is the task of studying people who have come to the fore in fields such as science, art, history, and politics in terms of teaching purposes (Öncül, 2000).

When it is considered that the subject of the biography is a human and what a human being has done, the biography appears as a teaching tool that can be used not only in the field of literature, but also in many other fields (Öztürk \& Otluoğlu, 2003). There are many advantages to the biography method. With the help of this technique, students learn many variables such as place, time, people, war, peace, political, social, and economic situations from different angles. In addition, this technique provides the understanding of common ground in different cultures, especially by teaching critical thinking, empathy, decision-making, virtue, and that all people have similar characteristics (Levstik, 1995; Maxim, 1999; Warren, 1992; Zarnowski, 2003). In this sense, especially, Kaufman and Libby (2012) and Oatley (1999) stated that such teaching techniques should be used to confront students' beliefs, and that biographical texts strongly influence people's attitudes, beliefs, and behaviours. Miall and Kuiken (1998) argued that stories originating from biographical texts shape people's perspectives and feelings. On the other hand, Zak (2014) suggested that 
individuals could benefit from using biographical texts when one wants to motivate, persuade, and remember. In a sense to support this, Black and Bower (1980) stated that such biographical texts provide long-lasting knowledge, and in such texts, people either see the world as it is or create similar situations by establishing an emotional relationship between the lives of the people whose biographies are given.

As mentioned above, biographical texts can be used in many fields, as well as in science teaching (Eshach, 2009; Hong \& Siegler, 2012; Martin \& Brouwer, 1993; McKinney \& Michalovic, 2004; Solomon, 2007). Solomon (2007) indicated that biographical texts can serve as role models for students. The fact that these scientists did not give up their studies despite the many problems they had to fight in social life leads students to the conclusion that their own struggles and the struggles of scientists are common, by revealing an emotional approach to the students (Hong \& Siegler, 2012). Thus, students feel the need to reconsider their current perceptions about scientists and their beliefs by concluding that everyone has a story through biographical texts (Hong \& Siegler, 2012). In this sense, Parker (1996) argued that biographical texts provide concrete satisfaction of events by shaping the pleasure of imagining. In addition, students expressed that biographical texts gave them a new way of thinking by giving them a life lesson and can bring about a change in their attitudes by focusing on the difficulties experienced by people and helping them to solve their own problems. In this context, the thought about the importance of science and attitudes towards it shows itself once again.

\subsection{Science teaching and student attitudes}

According to Çepni, Ayas, Johnson, and Turgut (1996), science is defined as approaching natural phenomena with critical thought and generalizing and reaching principles. According to Bloom (1979), it is an effort to make predictions about events that have not yet been observed by systematically examining natural events. Students who take science courses become individuals who can bring the mind to the forefront, think logically and make analytical analysis, communicate actively with both the environment and the world, make experiments and observations and express their results in words and maths, and become individuals (Akgün, 2004). Although all of these are possible for healthy science-literate individuals, they can be achieved by taking an interest in science topics and developing a positive attitude (Çakır \& Şenler, 2007). Accordingly, it is beneficial to take the concept of attitude and look at its definition and features. 
According to Bloom (1979), it is a bipolar situation - the state of liking the course and showing positive affective qualities about the course by developing positive thoughts about a course or a topic, or that has negative affective characteristics due to developing negative thoughts and disliking the lesson. Individuals primarily have prior knowledge about the object of the attitude, and then express it as an emotional response. In the last step, they transform attitudes into behaviour, and evaluate them as responding to the reactions from their environment. Köklü (1992) explains this situation as the positive and negative reactions that individuals develop against any stimulus which manifest as an attitude, by stating that most of the affective behaviours constitute the attitude. Although different meanings of attitude appear, Oppenheim (1992) made an attitude assessment in terms of education. That is, when faced with a certain stimulus, it warns that the person who reacts in a certain way to this stimulus. Küçükahmet (1997) states that students' attitudes and habits are one of the most essential factors that reveal their success. Similarly, Senemoğlu (2004) evaluates the internal state that affects the choice of individuals in their activities as attitude. Yllmaz et al. (1998) argue that attitudes are not behaviours, but are psychological variables that direct human behaviour, and state that attitudes have three dimensions. These are cognitive, affective and behavioral, and one's beliefs about attitude take place in the cognitive dimension. Cognitive beliefs create the perception that science course is difficult to learn. Affective responses of individuals about attitudes form the affective dimension. Affective dimension reveals students' feelings such as love or hate towards science course. Behavioral dimension, on the other hand, includes the actions of students regarding the subject of attitude.

When one is focussed on the attitude in terms of learning processes it can be seen that, unlike knowledge and abilities, attitudes appear in learning as a determinant and result. This is especially true of the attitude towards science concepts consists of mythos and beliefs of the person against these concepts. The emergence of these beliefs is particularly effective in choosing the science course, curiosity about scientific topics, or the development of science-related hobbies (White, 1993: cited in Atasoy, 2002). Since students' attitudes towards any course or topic are closely related to success, there are many studies on this topic. The correlation between learning and attitude reveals many dimensions related to attitude. Among these dimensions, especially self-confidence, socio-economic status, gender, age, teacher attitude, methods, and techniques used, and students' motivation coefficient are the dimension axes. It is among the results of many studies that students with low motivation 
towards the course will not be too successful in that course. As a result of the students losing their motivation, feelings of burnout emerge towards the lesson such as "I can't succeed", "It's too late", and "That's all from me" (Çakır \& Şenler, 2007). Altınok (2004) drew attention to the close relationship between success and motivation in a study he conducted. As a result of the research, a close relationship was found between the science course and the motivation towards this course. Açlkgöz (2003) gives advice, especially for teachers. He says that it would be beneficial to know in advance the motivation levels of the students about the course which the teachers are presenting to them. He states that knowing the motivation of the students in advance can be helpful in terms of which methods and techniques the teacher will use, as well as in increasing students' attitudes towards the lesson.

Hemlick and Norland (1994) emphasize that teachers should consider these learning approaches in students because students' learning methods will occur differently. Supporting this result, Mordi (1991) found that learning and teaching approaches were higher than other parameters (socio-economic status, student characteristics, school characteristics) - a rate of $41 \%$ in the study he conducted on students' attitudes towards science. Similarly, Baykul (1990) emphasized that the attitude of students towards science decreases from the fifth grade of primary school due to the teachers' attitude towards the lessons and the content of the textbooks. In a study conducted by Bilgin et al. (2002), they stated that student-centred teaching approaches not only revealed positive results in their achievement in a chemistry course, but also brought about positive changes in their attitudes towards the chemistry course. In a study conducted by Hendley, Stables, and Stables (1996) with 190 students in terms of the emotions revealed towards the science course, they found that although the science course was the fifth most popular among 12 courses, it ranked first among the three unpopular courses.

\section{Methodology}

\subsection{Research Design}

This study was mixed-method research, in which quantitative and qualitative methods were used to determine the effects of social biographical texts of scientists on students' attitudes according to science teachers. Creswell (2006) states that the basic proposition in mixed approach should be used together with quantitative and qualitative approaches, in order to better understand the research problem. In line 
with this proposition, the research question in the mixed method design is both better understood and in detail by obtaining multiple data (Alkan, Şimşek, \& Erbil, 2019).

This study used a sequential explanatory design, one of the mixed-method designs. The purpose of the sequential explanatory design is to begin the research problem with the quantitative stage for both data collection and analysis, and to then conduct a qualitative study to explain the quantitative results. Quantitative results present the general results of the study by providing statistical significance, confidence intervals, and effect sizes. However, this method is not enough to explain how the results are formed. For this reason, the pattern in which the qualitative stage is activated to explain the quantitative results is defined as sequential explanatory design (Creswell, 2017). In this design, qualitative results are used to help explain and interpret the findings of a quantitative study, and a sequential explanatory design can be useful - especially when an unexpected difference occurs between the results or opinions in a quantitative study (Morse, 1991; cited in Creswell, Plano Clark, Gutmann \& Hanson, 2003).

Quantitative phase: The quantitative part of the research was conducted based on the survey model (Karasar, 2012), which aims to describe the existing situation as it is. In this sense, the quantitative section consists of the repertory grid technique applied to teachers in order to evaluate the change in students' attitudes as a result of explaining and teaching the social biographical texts of scientists.

Qualitative phase: The qualitative part of the research consists of two stages. At the first stage, focus group interviews were conducted with the teachers who volunteered. The findings of these focus group interviews were used to determine the constructs in the repertory grid used in the quantitative part of the study. Then, the repertory grid technique was applied quantitatively. The findings obtained from these quantitative data were used to determine the participants in the individual interviews, which was the last stage of the research. Individual interviews were conducted with teachers in order to obtain in-depth information about how social biographical texts of scientists changed students' attitudes and behaviors towards the science course.

\subsection{Participants}

The study group of this research consisted of 51 science teachers who worked in different schools in Erzurum in Turkey and were determined according to convenience sampling method. The teachers were informed before the study and they volunteered to participate in the study. The names of the schools were coded and the 
numbers of science teachers participating in the study in each school are given in Table 1.

Table 1. Participating schools and number of science teachers in these schools

\begin{tabular}{cc}
\hline Schools & Number of teachers \\
\hline A & 2 \\
B & 2 \\
C & 2 \\
D & 1 \\
E & 5 \\
F & 4 \\
G & 2 \\
H & 7 \\
I & 2 \\
J & 1 \\
K & 5 \\
L & 6 \\
M & 7 \\
N & 4 \\
O & 1 \\
\hline Total & 51 \\
\hline
\end{tabular}

\subsection{Data Collection Tools}

In this study, as data collection tools, the focus group interview, the Repertory Grid Technique (RGT), and a semi-structured interview form were used.

\subsubsection{Focus group interview}

The focus group interview is a technique of interviewing selected participants based on a previously determined topic to reveal their knowledge and opinions. Focus group interviews are usually conducted with 10-12 people at one time. The interview is conducted by an expert and is conducted in order to reveal details about the thoughts and lives of the people. The data is analyzed and a synthesis of the evaluations expressed by the participants is made. Focus group interviews are a technique that steer decisions or action plans, either alone or with the help of the results obtained from quantitative studies (Ylldırım \& Şimşek, 2008).

In this study, focus group interviews were conducted with teachers in order to determine which attitudes of their students towards the science courses in which social content biographical texts were affected. Focus group interviews were held in three groups of 12 people who volunteered to participate in these interviews and lasted 
about 45 minutes per interview. In the focus group interviews, the participants were asked questions about the social content biographical texts of the scientists determined beforehand. The questions were chosen as questions about the difficulties faced by scientists in their social lives, rather than questions revealing the academic and intellectual aspects of these scientists. As a result of the analysis of the answers obtained from these questions, a decision was made about the structures to be included in the RGT. Table 2 shows the numbers of teachers who participated in the focus group interview.

Table 2. Number of teachers participating in focus group interviews

\begin{tabular}{ccc}
\hline School & Group No & Number of teachers \\
\hline A & 1 & 7 \\
B & 1 & 5 \\
C & 2 & 6 \\
D & 2 & 4 \\
E & 2 & 2 \\
F & 3 & 7 \\
G & 3 & 4 \\
H & 3 & 1 \\
\hline & Total & 36
\end{tabular}

\subsubsection{Repertory Grid Technique}

Personal construct psychology (PCP), which was founded by George A. Kelly in the 1950s, is known as the theory of individual and group psychological social processes, which is made to model the cognitive processes of people. The constructs that the person creates as a result of the guidance of their experiences create a subjective world, and the person act according to the structures create in this world. It is extremely important to reach these constructs created by people in order to understand a person and their actions. The repertory grid technique takes the stage at this point and aims to reach these structures. Through interviews, people question their structures and try to reveal the subjective world they have (Abazaoğlu, 2009).

Kelly says that a certain number of constructs can be reached as a result of evaluating the events that constitute one's world. Kelly defines events as 'elements' and states that the structures that individuals will have should be considered as bipolar. The constructs used in the repertory grid technique should be considered as a prediction used to present the person's world. The basis of the repertory grid technique is to create the constructs used to spread the intensity of meaning to a 
particular set of elements, and then score the elements of it according to the structures that are formed (Kelly, 1995).

Persons, institutions, objects, thoughts, and events are the main parameters that make up the elements in the repertory grid. The elements are generally shaped according to the subject researched by the researcher. The researcher and the participant can determine the items and structures in the repertory grid together. Constructs mostly manifest themselves as polar structures expressing similarity, contrast, and relationship between elements. The researcher directs the items to the participant in groups of two and asks about the similar and different aspects between them. The researcher reaches the constructs from the answers they receive.

The table constituting the repertory grid consists of the signs and numbers placed in the table by the participant as a result of the evaluation of the item according to the constructs and elements placed transversely and longitudinally. Jankowicz (2004) states that the repertory grid technique can be used in many areas. In terms of education, it appears more as a measurement and evaluation tool (Fatherstonhaugh, 1994; Winer \& Abad, 1995; Aztekin, 2008; Abazaoğlu, 2009).

In this study, Repertory Grid Technique (RGT) was conducted to 51 science teachers to evaluate the change in students' attitudes, when social biographical texts were taught. The RGT applied in this study was a matrix consisting of six elements and eight constructs (Table 3). While the elements consisted of biographical texts with social content, the constructs were the attitudes of the students towards the science course. Focus group interviews were taken into account in the creation of the constructs. The repertory grid created for the study was completed by the participants by scoring between one and five. A total of 48 cells were scored by giving values to eight structures over six items. In the repertory grid created for this study, the maximum score of a teacher's grid was $240(48 \times 5)$ and the minimum score was 48 $(48 \times 1)$. As the scores of the participants increased, it meant that the participants thought that social biographical texts could affect students positively. 
Table 3. Repertory grid

\begin{tabular}{|c|c|c|c|c|c|c|c|}
\hline $\begin{array}{l}\text { Constructs } \\
\text { Negative pole (1) }\end{array}$ & 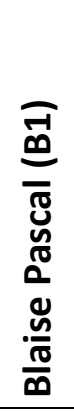 & 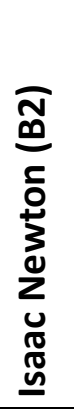 & 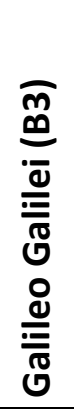 & 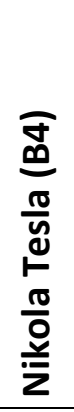 & 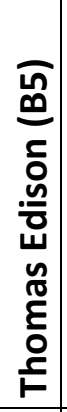 & 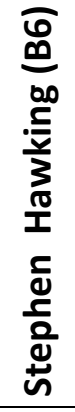 & $\begin{array}{l}\text { Constructs } \\
\text { Positive pole (5) }\end{array}$ \\
\hline Increases anxiety & & & & & & & Reduce anxiety \\
\hline Decreases interest & & & & & & & Increases interest \\
\hline Decreases motivation & & & & & & & Increases motivation \\
\hline Decreases academic success & & & & & & & Increases academic success \\
\hline Increases prejudice & & & & & & & Reduces prejudice \\
\hline $\begin{array}{l}\text { Decreases the level of } \\
\text { participation in activities }\end{array}$ & & & & & & & $\begin{array}{l}\text { Increases the level of } \\
\text { participation in activities }\end{array}$ \\
\hline Decreases laboratory tendency & & & & & & & Increases laboratory tendency \\
\hline Decreases questioning skills & & & & & & & Increases questioning skills \\
\hline
\end{tabular}

\subsubsection{Semi-structured interviews}

Interviewing is one of the research methods widely used in social sciences. Briggs (1986) states that interviewing is a data collection method frequently used in social sciences research. Stewart and Cash (1985) define the interview as an interactive communication process based on asking and answering questions for a predetermined purpose. In this sense, the interview is quite different from ordinary conversation. Patton (1987) states that the main purpose of an interview is to examine the perspective of the individual by entering the inner world. Three types of interview are mentioned in the literature. These are: 'structured interview,' 'semi-structured interview,' and 'unstructured interview.' Structured interviews include predetermined questions, while unstructured interviews include more open-ended questions (Chadwick, Bahr, \& Allbrecth, 1984). Semi-structured interviews are more flexible than structured interviews. In this type of interview, the researcher prepares the interview protocol which includes the questions they plan to ask beforehand. The greatest convenience provided by the semi-structured interviews to the researcher enables systematic and comparable information to be obtained by conducting the interview according to the previously prepared interview protocol (Ylldırım \& Şimşek, 2008).

In this study, semi-structured interviews were conducted with teachers $(\mathrm{N}=15)$ with the highest scores in the repertory grid. In this sense, taking into account the 
results obtained from RGT, which is used as a quantitative measurement tool, a 'Teacher Interview Form' was prepared by the researchers. There were six open-ended questions in the interview form. The interview form was applied to the participants after the concerns about validity were eliminated as a result of both the expert opinions and the pilot scheme. The main criterion in the selection of the teachers to be interviewed was the teachers with high repertory grid scores. Table 4 shows the repertory grid scores of the teachers who participated in the interview.

Table 4. Repertory grid scores of teachers participating in the interview

\begin{tabular}{ll}
\hline Teachers & Repertory grid scores \\
\hline T1 & 109 \\
T2 & 109 \\
T3 & 109 \\
T4 & 109 \\
T5 & 109 \\
T6 & 108 \\
T7 & 107 \\
T8 & 106 \\
T9 & 105 \\
T10 & 104 \\
T11 & 104 \\
T12 & 104 \\
T13 & 102 \\
T14 & 102 \\
T15 & 102 \\
\hline
\end{tabular}

\subsection{Data collection process}

The lessons were carried out in the science courses with 51 science teachers. Focus group interviews were conducted within three groups of 36 science teachers, in order to find the structural equivalent of the biographical texts on social life. The interviews conducted in a suitable classroom environment took approximately 50 minutes. The interviews were videotaped with the consent of the participants. After the focus group interviews, a list of the biographical texts of the scientists selected beforehand which would be taught in the science course was given to the teachers who would participate in the study. The contents of the selected biographical texts consisted of texts that included social life and the problems encountered in the lives of the scientists rather than showing their intellectual and academic achievements. In other words, the problems faced by selected scientists in social lives and affecting their private lives constituted the main theme of the biographical texts. Before the biographical texts 
were applied, the opinions of two researchers who were experts in the field of education were taken. Problems with validity were corrected by the same expert group and then applied by the participants. Teachers were asked to explain social biographical texts to students over a total of 48 lessons, in science courses, and they were asked to evaluate the changes caused by the constructs included in the repertory grid in students' attitudes towards the science course. The lessons continued for three months, and for three months after the lessons the teachers observed the attitude changes in the students towards the science course. After the three-month application, the repertory grid technique was applied to the teachers in order to evaluate the changes in students' attitudes towards science from their own perspective. After the grid analysis, teachers with high RGT scores were identified and a proposal was made to interview them. Semi-structured individual interviews were conducted with 15 teachers who accepted the interview. For this, the interview forms prepared were used. The interviews lasted about 60 minutes. The interviews were recorded with the approval of the participant. The interviews were then transcribed and made ready for analysis. In Table 5, information about the application process of social biographical texts belonging to scientists is given.

Table 5. Biographical Texts Application Process

\begin{tabular}{llllllllll}
\hline Months & \multicolumn{3}{l}{ SCIENTISTS } & & & & $\begin{array}{l}\text { Time } \\
\text { (minutes) }\end{array}$ & $\begin{array}{l}\text { Text size } \\
\text { (word } \\
\text { count) }\end{array}$ \\
\cline { 2 - 6 } & B1 & B2 & B3 & B4 & B5 & B6 & & \\
\hline 1 & $X$ & $X$ & & & & & 960 & 1576 \\
2 & & & $X$ & $X$ & & & 960 & 1470 \\
3 & & & & & $X$ & $X$ & 960 & 1516 \\
TOTAL & & & & & & & $\mathbf{2 8 8 0}$ & $\mathbf{4 5 6 2}$ \\
\hline
\end{tabular}

\subsection{Data analysis}

The analysis of the data in this study consists of three stages. In the first stage, focus group interviews with the participants were analyzed in order to discover the constructs to be included in the RGT. In the second step, the sum of the values given by the participants to the repertory grid applied to the constructs in the grid and their frequencies were determined. In the third stage, descriptive and content analysis was used in order to examine the results of the quantitative analysis in depth (Yldirım \& Şimşek, 2008). 


\subsubsection{Analysis of Focus Group Interviews}

For the analysis of the focus group interviews, first of all the camera recordings were transcribed and transferred to a written environment. Later, the transcribed interview records of each group were subjected to content analysis by the researcher, and the student attitudes which social biographical texts could affect the science lesson the most were coded. Sub-categories were reached with the help of the codes obtained and constructs were obtained with the help of these sub-categories. These constructs have taken their place as the attitude situations that formed the basis for the subsequent RGT.

\subsubsection{Analysis of Repertory Grids}

The calculation table prepared in Excel by the researchers was used to calculate the participant scores of the RGT applied to 51 participants. With this table, the RGT scores of each participant were calculated and shown in a table. The SPSS 20 package program was used to find the frequencies of the values given by the participants to the constructs in the RGT, which consisted of six elements and eight constructs.

\subsubsection{Analysis of individual interviews}

Data obtained from individual interviews was analyzed using content analysis. Content analysis is defined as a systematic renewable technique in which some words of a text are summarized with smaller content categories, with codings based on certain rules (Yldırım \& Şimşek, 2008). The main purpose of content analysis is to reach concepts and relationships that can explain the collected data. In the descriptive approach, unnoticed concepts and themes can be obtained through content analysis (Patton, 1990; Miles \& Huberman, 1994; Yıldırım \& Şimşek, 2008). Coding and subcategorization were carried out repeatedly by the researchers. Thus, unnecessary codings were removed by adhering to the problems and sub-problems of the research, and new codings were added where necessary. As a result, tables showing the opinions of the participants about the questions were obtained during the interviews. Subcategories were determined by coding the data obtained from the interviews with the help of explanatory categories. 


\section{Findings}

Under this heading, focus group interviews, RGT scores, and individual interview results are interpreted. First of all, in the focus group interviews it was determined what attitudes of the students could be revealed in the science course due to studying social biographical texts according to the teachers. Later, the RGT scores of the teachers to whom RGT was applied were calculated and interpreted. Following this, the frequencies of the points given by the teachers to the constructs in the RGT were analyzed and interpreted with SPPS. Finally, semi-structured individual interviews were analyzed and interpreted.

\subsection{Findings obtained from focus group interviews}

Table 6 shows the focus group interview results of all three groups. In focus group interviews, teachers stated that social biographical texts could affect students' characteristics such as anxiety, interest, motivation, prejudice, participation in activities, laboratory tendency, and questioning skills. In terms of students' attitudes towards science, the construct of interest was repeated thirteen times by the teachers in all three groups and ranked first. This was followed by the anxiety construct with 12 repetitions. These repeated constructs continued as motivation 10, prejudice 8 , participation in activities 9, laboratory tendency 11, and questioning skills 10. Among these structures, the academic achievement structure showed itself as the lowest structural repetition frequency with five. This shows that although the teachers believed that biographical texts with social content will not increase or decrease the academic success of the students, they also saw it as a weak situation that may be revealed in students. 
Table 6. The constructs that emerged in focus group interviews

\begin{tabular}{|c|c|c|c|c|c|}
\hline Codes & $\begin{array}{l}\text { Code } \\
\text { Symbol }\end{array}$ & $\begin{array}{l}\text { Frequency } \\
\text { (f) }\end{array}$ & Definition of Codes & Sub Categories & Constructs \\
\hline $1 a$ & $1 \mathrm{aT13}$ & 13 & $\begin{array}{l}\text { Like or dislike the } \\
\text { object }\end{array}$ & $\begin{array}{l}\text { Be interested in the } \\
\text { object }\end{array}$ & interest \\
\hline $2 b$ & $2 \mathrm{bT} 12$ & 12 & Alienating the object & $\begin{array}{l}\text { Approaching the } \\
\text { object with anxiety }\end{array}$ & anxiety \\
\hline $3 c$ & $3 c T 10$ & 10 & $\begin{array}{l}\text { To demonstrate the } \\
\text { awareness of the } \\
\text { object }\end{array}$ & $\begin{array}{l}\text { Motivation against } \\
\text { the object }\end{array}$ & motivation \\
\hline $4 d$ & $4 \mathrm{dT5}$ & 5 & $\begin{array}{l}\text { To make an effort } \\
\text { against the object }\end{array}$ & $\begin{array}{l}\text { Academic success in } \\
\text { the object }\end{array}$ & academic success \\
\hline $5 e$ & $5 \mathrm{eT} 8$ & 8 & $\begin{array}{l}\text { Emotional reactions to } \\
\text { the object }\end{array}$ & $\begin{array}{l}\text { To be biased towards } \\
\text { the object }\end{array}$ & prejudice \\
\hline $6 f$ & $6 f T 9$ & 9 & $\begin{array}{l}\text { To show yourself } \\
\text { against the object }\end{array}$ & $\begin{array}{l}\text { Common behaviour } \\
\text { with the object }\end{array}$ & $\begin{array}{l}\text { participation in } \\
\text { activities }\end{array}$ \\
\hline $7 g$ & 7gT11 & 11 & $\begin{array}{l}\text { Associating the object } \\
\text { with evidence }\end{array}$ & $\begin{array}{l}\text { Experimental proof of } \\
\text { the object }\end{array}$ & laboratory tendency \\
\hline $8 \mathrm{~h}$ & $8 \mathrm{hT} 10$ & 10 & Evaluation the object & $\begin{array}{l}\text { Performing } \\
\text { participatory roles } \\
\text { about the object }\end{array}$ & questioning skills \\
\hline
\end{tabular}

\subsection{Repertory grid scores}

Table 7 shows the RGT scores of each participant. Considering the scores, it was found that the teachers generally observed that biographical texts about the social life of scientists revealed positive attitudes towards science in students. 
Table 7. RGT Scores of teachers

\begin{tabular}{llllll}
\hline $\begin{array}{l}\text { Teacher } \\
\text { Code }\end{array}$ & $\begin{array}{l}\text { RGT } \\
\text { Score }\end{array}$ & $\begin{array}{l}\text { Teacher } \\
\text { Code }\end{array}$ & $\begin{array}{l}\text { RGT } \\
\text { Score }\end{array}$ & $\begin{array}{l}\text { Teacher } \\
\text { Code }\end{array}$ & $\begin{array}{l}\text { RGT } \\
\text { Score }\end{array}$ \\
\hline T1 & 109 & T18 & 101 & T35 & 91 \\
T2 & 109 & T19 & 101 & T36 & 90 \\
T3 & 109 & T20 & 101 & T37 & 90 \\
T4 & 109 & T21 & 96 & T38 & 87 \\
T5 & 109 & T22 & 95 & T39 & 87 \\
T6 & 108 & T23 & 95 & T40 & 87 \\
T7 & 107 & T24 & 95 & T41 & 87 \\
T8 & 106 & T25 & 95 & T42 & 87 \\
T9 & 105 & T26 & 95 & T43 & 87 \\
T10 & 104 & T27 & 95 & T44 & 87 \\
T11 & 104 & T28 & 95 & T45 & 87 \\
T12 & 104 & T29 & 92 & T46 & 87 \\
T13 & 102 & T30 & 92 & T47 & 87 \\
T14 & 102 & T31 & 91 & T48 & 85 \\
T15 & 102 & T32 & 91 & T49 & 85 \\
T16 & 101 & T33 & 91 & T50 & 85 \\
T17 & 101 & T34 & 91 & T51 & 85 \\
\hline
\end{tabular}

Table 8 shows the frequencies of scores given to the constructs in the RGT of the social biographical texts of scientists. When Table 8 is examined, teachers rated four and five points to seven constructs out of eight constructs in RGT means that teachers have observed that biographical texts have developed positive attitudes. However, within these frequencies, "increases academic achievement" construct was coded as "decreases academic success," which is the opposite structure by the participants. In other words, the teachers do not think that social biographical texts will increase the academic success of the students in the science course. Therefore, one of the interesting results of this study that the relationship between social biographical texts and academic achievement did not come out as expected. 
Table 8. Frequencies of the constructs in RGT

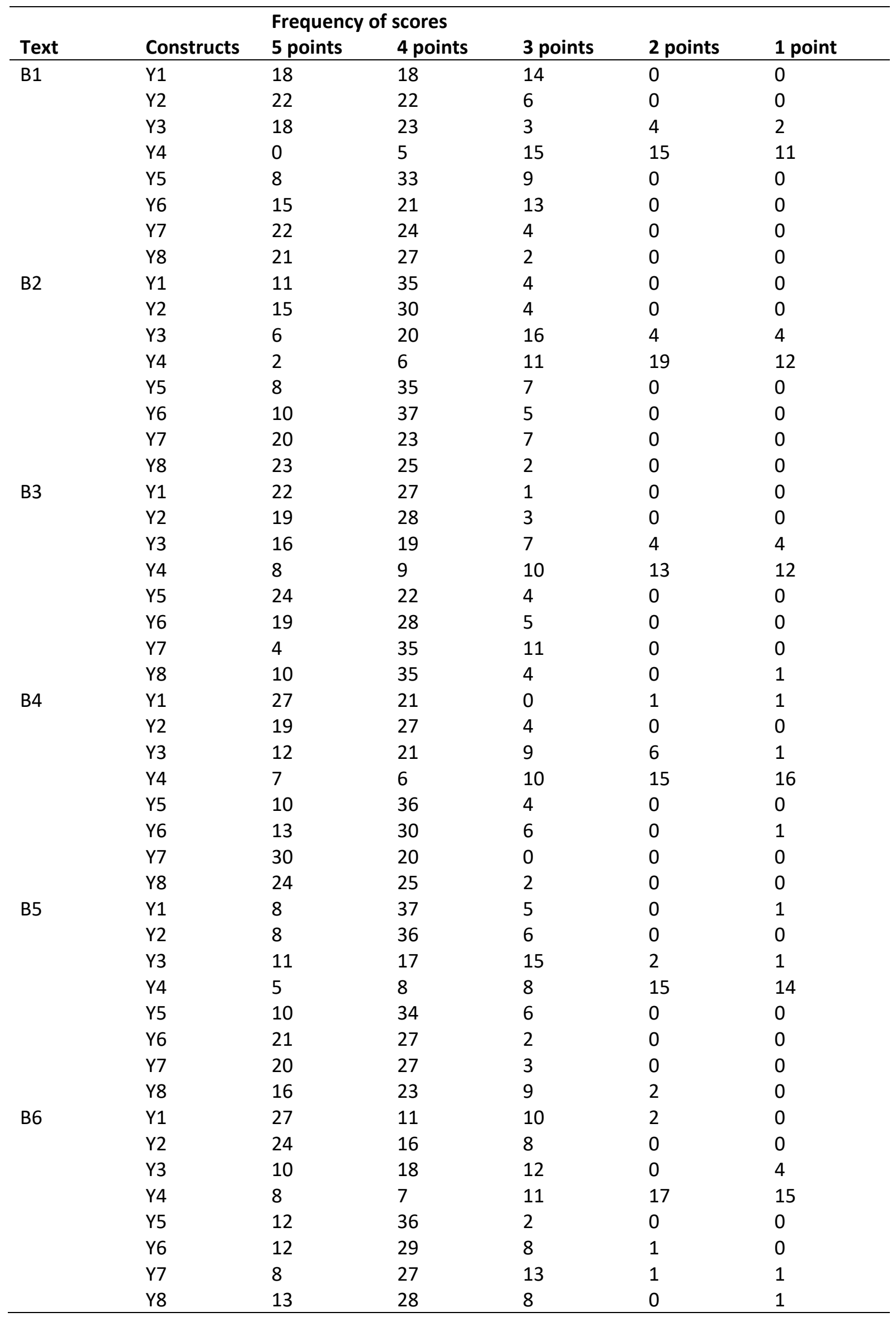




\subsection{Findings obtained from individual interviews}

\section{Table 9 shows the codes, subcategories, and quotations obtained from individual interviews.}

Table 9. Codes, subcategories, and teacher quotations obtained from individual interviews.

\begin{tabular}{|c|c|c|c|c|c|c|c|}
\hline $\begin{array}{l}\text { Descriptive } \\
\text { Categories }\end{array}$ & $\begin{array}{l}\text { Descriptive } \\
\text { Category } \\
\text { Symbol }\end{array}$ & Codes & $\begin{array}{l}\text { Code } \\
\text { Symbol }\end{array}$ & $\begin{array}{l}\text { Frequency } \\
\text { (f) }\end{array}$ & $\begin{array}{l}\text { Sub- } \\
\text { Categories }\end{array}$ & $\begin{array}{l}\text { Sub- } \\
\text { Category } \\
\text { Symbol }\end{array}$ & Quotes from teachers \\
\hline $\begin{array}{l}\text { Biographical } \\
\text { text, science } \\
\text { teaching, and } \\
\text { importance }\end{array}$ & BTSTI & $\begin{array}{l}\text { Academic } \\
\text { success } \\
\text { Perspective }\end{array}$ & $\begin{array}{l}1 \mathrm{aT7} \\
1 \mathrm{bT6}\end{array}$ & 7 & $\begin{array}{l}\text { The } \\
\text { success } \\
\text { that } \\
\text { cannot be } \\
\text { achieved } \\
\text { easily }\end{array}$ & SCNAE & $\begin{array}{l}\text { Science curriculum is done } \\
\text { outside of the teacher. } \\
\text { Biographical texts are mostly } \\
\text { absent in teaching programs. } \\
\text { No academic achievement can } \\
\text { be achieved easily. } \\
\text { Social biographies can change } \\
\text { students' perspectives. }\end{array}$ \\
\hline $\begin{array}{l}\text { Biographical } \\
\text { text and } \\
\text { content }\end{array}$ & BTC & $\begin{array}{l}\text { Struggle } \\
\text { Success }\end{array}$ & $\begin{array}{l}2 \mathrm{aT6} \\
2 \mathrm{bT6}\end{array}$ & $\begin{array}{l}6 \\
6\end{array}$ & $\begin{array}{l}\text { Social life } \\
\text { facts }\end{array}$ & SLF & $\begin{array}{l}\text { Social life is not taught much. } \\
\text { Social life is a fact that reveals } \\
\text { academic success. } \\
\text { The part that concerns us is the } \\
\text { struggle with the difficulties } \\
\text { and the success achieved as a } \\
\text { result. }\end{array}$ \\
\hline $\begin{array}{l}\text { Academic } \\
\text { achievement, } \\
\text { Biographical } \\
\text { text, and } \\
\text { Consistency }\end{array}$ & AABTC & $\begin{array}{l}\text { Bad } \\
\text { reputation } \\
\text { Clarity }\end{array}$ & $\begin{array}{l}3 a T 8 \\
3 b T 5\end{array}$ & $\begin{array}{l}8 \\
5\end{array}$ & $\begin{array}{l}\text { Facts } \\
\text { about life }\end{array}$ & $\mathrm{FL}$ & $\begin{array}{l}\text { Facts about life. } \\
\text { These facts bring up many } \\
\text { material and spiritual } \\
\text { consequences. } \\
\text { Situations like this are not } \\
\text { taught very much. } \\
\text { These situations can provoke a } \\
\text { bad reputation for the scientist. } \\
\text { I think clarity should be very } \\
\text { important in biographies. }\end{array}$ \\
\hline $\begin{array}{l}\text { Social life, } \\
\text { Challenge, } \\
\text { and success }\end{array}$ & SLCS & $\begin{array}{l}\text { Attention } \\
\text { Interest }\end{array}$ & $\begin{array}{l}4 a T 7 \\
4 b T 6\end{array}$ & $\begin{array}{l}7 \\
6\end{array}$ & $\begin{array}{l}\text { Dramatized } \\
\text { lives }\end{array}$ & $\mathrm{DL}$ & $\begin{array}{l}\text { Many things are mentioned in } \\
\text { biographies. } \\
\text { Social life should be the part } \\
\text { that needs to be told more. } \\
\text { Social life imposes a dramatic } \\
\text { identity on scientists. } \\
\text { Dramatization always works. } \\
\text { I would prefer such a method } \\
\text { in biographies to attract } \\
\text { attention. }\end{array}$ \\
\hline $\begin{array}{l}\text { Social life, } \\
\text { Difficulty, } \\
\text { Success, } \\
\text { Biographical } \\
\text { presentation } \\
\text { and Method }\end{array}$ & SLDSM & $\begin{array}{l}\text { Emotional } \\
\text { identity } \\
\text { Scientific } \\
\text { skill }\end{array}$ & $\begin{array}{l}5 a T 8 \\
5 b T 5\end{array}$ & 8 & $\begin{array}{l}\text { Getting } \\
\text { away from } \\
\text { objectivity }\end{array}$ & GAO & $\begin{array}{l}\text { There are ways of presentation } \\
\text { according to the purpose in } \\
\text { biographical presentations. } \\
\text { Biographical presentations } \\
\text { about social life reveal overly } \\
\text { emotional identities. } \\
\text { Emotional identities distract } \\
\text { objectivity. }\end{array}$ \\
\hline $\begin{array}{l}\text { Biographical } \\
\text { text, Science } \\
\text { and }\end{array}$ & BTSAA & $\begin{array}{l}\text { Education } \\
\text { system } \\
\text { Culture }\end{array}$ & $\begin{array}{l}6 \mathrm{aT7} \\
\text { 6bT5 }\end{array}$ & 7 & $\begin{array}{l}\text { Values that } \\
\text { increase } \\
\text { emotions }\end{array}$ & VIE & $\begin{array}{l}\text { Social biographical texts } \\
\text { increase things like more } \\
\text { interest and motivation. }\end{array}$ \\
\hline
\end{tabular}




\section{Conclusion and Discussion}

In this study, it was aimed to determine the changes that may occur in the attitude of students towards the science course if they were taught social content biographical texts of scientists. Initially, focus group interviews with 36 science teachers were asked for teachers' opinions on which social biographical texts might affect students' attitudes. These attitudes were considered constructs. These constructs are determined as anxiety, interest, motivation, prejudice, participation in activities, laboratory tendency, and questioning skills. Of these constructs, the interest was the most recurring construct in focus group interviews. Similarly, in a study conducted by Aksakalli et al. (2016) using the repertory grid technique, students' perceptions of modern physics were determined. Among these perceptions, the perceptions of anxiety, interest, and alienation showed themselves as the most recurring perceptions.

The construct that increases academic achievement among the structures revealed as a result of focus group interviews has shown itself as the least repetitive structure by teachers. The fact that this construct has a low value among teachers has led to two important results. The first of these results - the thought that social biographical texts will not affect academic success positively. In a way that supports this result, teachers stated in their observations that after the biographical texts were taught in classrooms, the texts did not increase the academic success of the students. Another result revealed by this construct was that the participants did not consider the statement "social biographical texts increase the academic success of students" as an attitude.

Findings obtained from the repertory grid show that generally, teachers have a positive attitude towards social biographical texts. According to the findings, social biographical texts prevented students from approaching science with concern, but also made them more interested. In addition to this, it has shown that the rate of participation in activities increased as well as increasing their motivation. Similarly, as stated by Bandura (1986), association theory originating from biographical texts 
has important effects on success or failure. In this sense, it was seen as one of the results obtained in this study that biographical texts improved students' motivation to be in the laboratory, and they also go a long way in encouraging them to start asking more questions.

The results of the analysis of teachers' RGT scores indicated that among the eight constructs, seven of the eight constructs indicated a positive transformation, that is, five and four points, while one got relatively lower scores than the teachers. Teachers generally gave one or two points to the construct "increases academic achievement". The construct of "increasing academic achievement", which has the least frequency in focus group interviews, also has similar results in RGT. In other words, this study shows that teachers do not believe that social biographical texts belonging to scientists will increase the academic success of students in science courses, and that they did not observe a change in this direction in students after the applications.

Semi-structured interviews were conducted with the teachers who argued that social biographical texts would cause changes in students' attitudes. In terms of the importance of social biographical texts in science teaching, which is the first of six descriptive categories, the participants stated that such biographies would change the students' perspectives on science courses and approach them more positively, and they stated that every aspect of scientists' lives should be explained to students. Emphasizing that success cannot be achieved easily, they stated that how scientists struggle with difficulties in their lives should be reflected to students with an impartial eye.

The descriptive category on what should be the contents of biographical texts to be used in science course has emerged as the participants should include more challenges in life. They stated that biographical texts about how they cope with the difficulties in their social life would be more effective than their academic or intellectual achievements. The other data revealed by this descriptive category is an expression of success. The achievements achieved in biographical texts to be used in science, despite the difficulties in social life, have also been participants' statements that there should be content that should be used in such biographical texts. Regarding the rationality of constantly talking about their academic achievements in the narration of biographical texts of scientists, another descriptive category, the participants thought that such expressions would create a disadvantage in terms of hiding the social lives of scientists. In this respect, they stated that biographical texts 
should be as transparent as possible, and include statements explaining various aspect of scientists' lives.

The teachers stated that they observed that the success of a scientist despite the difficulties in his/her social life increased the students' interest and increased their respect for the scientist. On the other hand, it can be said that teachers were in favor of telling scientists' lives without overly dramatizing them. When scientists' lives were overly dramatized, students may miss the point they really need to focus on. Emotional identities were suggested by the participants to reveal more pity than respect to scientists. In this sense, teachers emphasized that their contribution to science should also be expressed by revealing the scientific skills aspects of scientists in biographical presentations. In terms of this descriptive category, although the participants expressed difficulties in social lives, they also emphasized that objectivity should not be avoided in biographical presentations.

Teachers were sceptical about whether social biographical texts would increase students' academic success in the science course. They thought that only biographical texts will not increase academic success. They stated that various studies are required to increase academic success. They stated that the increase or decrease in academic success is closely related to the education system. In this sense, they especially emphasized that the education system should be improved in this sense. They argued that incorrectly established or inoperative education systems reduce academic achievement and underlined that biographical texts with social content will not increase academic success. They also drew attention to the relationship between culture and biographical texts.

The following recommendations on the use of biographical texts in science courses can be taken into consideration:

- Biographical presentations should be considered as one of the methods be used in the science course.

- Time should be allocated for social biographical texts of scientists in science classes.

- Biographical presentations should be included more in the science curriculum.

- By recognizing the importance of biographical presentations in terms of interest and motivation, science teachers should discuss the biographical presentation method among themselves and bring them to the fore.

- The scientific value of the social biographies of scientists and their connection with cultural values should be brought to the fore. 
- Pedagogical issues should be raised, and it should be discussed that benefiting from biographical texts with social content affects students' motivation, interest, learning, and ability to do something about science.

\section{References}

Abazaoğlu, İ. (2009). Using repertory grid techniques in the force and motion subject (Unpublished Master Thesis). Gazi University, Institute of Educational Sciences, Ankara.

Açıkgöz, K. Ü. (2003). Effective Learning and Teaching. (4th Edition). İzmir: Education World Publications.

Akgün, Ş. (2004). Science teaching. Ankara: Nasa Publications.

Aksakalli, A., Salar, R., \& Turgut, U. (2016). Investigation of the reasons of negative perceptions of undergraduate students regarding the modern physics course. European Journal of Science and Mathematics Education, 4(1), 44-55. https://doi.org/10.30935/scimath/9452

Alkan, V., Şimşek, S., \& Erbil, B. A (2019). Mixed methods design: a narrative literature review. Journal of Qualitative Research in Education,7(2), 559-582.

https://doi.org/10.14689/issn.2148-2624.1.7c.2S.5m

Altınok, H. (2004). Teacher candidates' evaluation of their teaching competencies. Hacettepe University Journal of Education Faculty 26(26), 1-8.

Atasoy, B. (2002). Science learning and teaching. Ankara: Gündüz Education and Publishing.

Aztekin, S. (2008). Investigating of infinity concepts constructed in different age groups of students (Published Doctoral Thesis). Gazi University Institute of Educational Sciences, Ankara

Bandura, A. (1977). Social learning theory. Englewood Cliffs, NJ: Prentice Hall.

Bandura, A. (1986). Social foundations of thought and action: A social cognitive theory. Englewood Cliffs, NJ: Prentice Hall.

Baykul, Y. (1990). Changes in attitude towards mathematics and science classes from the 5 th grade of primary school to the final grades of high school and equivalent schools and some factors thought to be related to the success in the student placement exam. ÖSYM Publications, (1).

Bilgin, İ., Uzuntiryaki, E., \& Geban, Ö. (2002). Investigation of the effect of chemistry teachers 'teaching approaches on high school students' achievement and attitudes in chemistry course. V. National Science and Mathematics Education Congress, Ankara.

Black, J. B., \& Bower, G. H. (1980). Story understanding as problem solving. Poetics, 9(1-3), 223250. https://doi.org/10.1016/0304-422X(80)90021-2

Blickenstaff, J. C. (2005). Women and science careers: leaky pipeline or gender filter? Gender and Education, 17(4), 369-386. https://doi.org/10.1080/09540250500145072

Bloom, B.S. (1979). Human qualities and learning at school. (D. Ali Özçelik, Translation). Ankara: National Education Press.

Bown, W. (1993). Classroom science goes into free fall. New Scientist, 14O(1902), 12-13.

Briggs, C. (1986). Learning how to ask: A sociolinguistic appraisal of the role of the interview in social science research (No.1). Cambridge University Press. https://doi.org/10.1017/CBO9781139165990

Çakır, N.K., \& Şenler, B. (2007). Primary education II. determining the attitudes of level students towards science lesson. Turkish Journal of Educational Sciences, 5(4), 637-655. 
Çepni, S., Ayas, A., Johnson, D., \& Turgut, M. F., (1996). Physics teaching. Ankara: National Education Development Project Pre-Service Teacher Education, Trial Edition.

Chadwick, B. A., Bahr, H.M., \& Allbrecth, S.L. (1984). Social science research methods. Prentice Hall.

Chambers, D. W. (1983). Stereotypic images of the scientist: The Draw-a-Scientist Test. Science Education, 67(2), 255-265. https://doi.org/10.1002/sce.3730670213

Creswell, J. W. (2017). Introduction to mixed method research (Translation Ed.: M. Sözbilir). Ankara: Pegem Academy Publishing.

Creswell, J. W., Plano Clark, V. L., Gutmann, M. L., \& Hanson, W. E. (2003). Advanced mixed methods research designs. In A. Tashakkori \& C. Teddlie (Eds.), Handbook of mixed methods in social and behavioral research (209-240). Thousand Oaks, CA: Sage.

Creswell, J.W. (2006). Understanding mixed methods research, (Chapter 1). Accessed from http://www.sagepub.com/upm-data/10981_Chapter_1.pdf.

Davies, P. C. W., \& Davies, P. (1984). God and the new physics. Simon and Schuster.

Dweck, C. S. (2000). Self-theories: Their role in motivation, personality, and development. Philadelphia, PA: Psychology Press.

Dweck, C. S. (2010). Mind-sets and equitable education. Principal Leadership, 10, 26-29.

Eshach, H. (2009). The nobel prize in the physics class: science, history, and glamour. Journal of Science and Education, 18(10), 1377-1393. https://doi.org/10.1007/s11191-008-9172-4

Farland, D. (2006). The effect of historical, nonfiction trade books on elementary students' perceptions of scientists. Journal of Elementary Science Education, 18(2), 31-47. https://doi.org/10.1007/BF03174686

Fatherstonhaugh, T. (1994). Using the repertory grid to probe students' ideas about energy. Research in Science \& Technological Education, 112(2), 117-127. https://doi.org/10.1080/0263514940120202

Finson, K. D. (2002). Drawing a scientist: What we do and do not know after fifty years of drawing. School Science and Mathematics, 102(7), 335-345. https://doi.org/10.1111/j.19498594.2002.tb18217.x

Hemlick, J. E., \& Norland, E. V. (1994). I do believe in Santa? (Cover Story). Adult Learning, 3(5), 22-24. https://doi.org/10.1177/104515959400500311

Hendley, D., Stables,S., \& Stables, A. (1996). Pupils' subject preferences at key stage 3 in south wales. Educational Studies, 2(22), 177-186. https://doi.org/10.1080/0305569960220204

Hodson, D. (2008). Towards scientific literacy: A teachers' guide to the history, philosophy and sociology of science. Brill.

Hong, H., \& Lin-Siegler, X. (2012). How learning about scientists' struggles influences students' interest and learning in physics. Journal of Educational Psychology, 104(2), 469-484. https://doi.org/10.1037/a0026224

Jankowicz, D. (2004). The easy guide to repertory grids. Chichester (England): John Wiley \& Sons Ltd.

Karasar, N. (2012). Scientific research methods. Ankara: Nobel Publishing.

Kaufman, G. F., \& Libby, L. K. (2012). Changing beliefs and behavior through experience-taking. Journal of Personality and Social Psychology, 103(1), 1-19.

https://doi.org/10.1037/aoo27525

Kaymakçı, S., \& Er, H. (2009). The Usage of Biography in Social Studies Curricula and Textbooks (s. 414-428). M. Saffron (Ed). Ankara: Pegem A Publishing

Kelly, G.A. (1995). The psychology of personal constructs (vol.1). New York: W.W. Norton. 
Köklü, N. (1992). Developing an attitude scale towards research. Eğitim ve Bilim Dergisi, 86(16), 27-36.

Küçükahmet, L. (1997). Teaching principles and methods. Ankara: Gazi Büro Publishing House.

Levstik, L. (1995). Narrative constructions: cultural frames for history. The Social Studies, 86(3), 113-116. https://doi.org/10.1080/00377996.1995.9958381

Lin-Siegler, X., Ahn, J. N., \& Chen, J. (2016). Even Einstein struggled: Effects of learning about great scientists' struggles on high school students' motivation to learn science. Journal of Educational Psychology, 108(3), 314-328. https://doi.org/10.1037/eduo000092

Martin, B., \& Brouwer, W. (1993). Exploring personal science. Science Education, 77, 441-459. https://doi.org/10.1002/sce.3730770407

Matthews, M. R. (1992). History, philosophy, and science teaching: The present rapprochement. Science \& Education, 1(1), 11-47.

Matthews, M.R. (1991). History, philosophy and science teaching: Selected reading, OISE Press, Toronto.

Maxim, G. W. (1999). Social studies and the elementary school child. New Jersey: Prentice Hall. Mayer, J. (1987). Consequences of a weak science education, Boston Globe. September.

McKinney, D., \& Michalovic, M. (2004). Teaching the stories of scientists and their discoveries. Retrieved October 5, 2018. from

http://www.nsta.org/publications/news/story.aspx?id=49940.

Miall, D. S., \& Kuiken, D. (1998). The form of reading: empirical studies of literariness. Poetics, 25(6), 327-341. https://doi.org/10.1016/So304-422X(98)90003-1

Miles, M. B., \& Huberman, A.M. (1994). Qualitative data analysis: A sourcebook. Beverly Hills: Sage Publications.

Mordi, C. (1991). Factors associated with pupil's attitudes towards science in negerian primary schools. Research in Science and Techologial Education, 1(9), 39-41.

https://doi.org/10.1080/0263514910090104

National Academy of Science. (2005). History of the National Academics. Retrieved October 20, 2018 from http://www.nationalacademics.org/about/history.html

Oatley, K. (1999). Meetings Of minds: dialogue, sympathy, and identification, in reading fiction. Poetics, 26(5-6), 439-454. https://doi.org/10.1016/S0304-422X(99)ooo11-X

Öncül, R. (2000). Education and educational sciences dictionary. Istanbul: MEB Publishing House.

Oppenheim, A. N. (1992). Questionnaire design, interviewing and attitude measurement. London: Pinter Publishers.

Oruç, M. (1993). The Relations between attitudes toward their science lessons of the second stage students in elementary school. (Unpublished Master thesis). Hacettepe University, Turkey

Öztürk C., \& Otluoğlu, R. (2003). Literary works and written materials in social studies teaching. Ankara: Pegem A Publishing.

Parker, C. (1996). Biography: Writing lives. New York, NU: Twayne.

Patton, M. Q. (1987). How to use qualitive metods in evaluation. Newbury Park, CA:

Patton, M. Q. (1990). Qualitative evaluation and research methods. SAGE Publications, inc.

Schibeci, R. A., \& Sorensen, I. (1983). Elementary School Children's Perceptions Of Scientists. School Science and Mathematics, 83, 14-20. https://doi.org/10.1111/j.1949-

8594.1983.tb10087.x

Senemoğlu, N. (2004). Development learning and teaching. (1oth Edition). Ankara: Gazi Publishing House. 
Shumow, L., \& Schmidt, J. A. (2014). Enhancing adolescents' motivation for science. Thousand Oaks, CA: Sage.

Singh, K., Granville, M., \& Dika, S. (2002). Mathematics and science achievement: effects of motivation interest and academic engagement. The Journal of Educational Research, 95(6), 323-332. https://doi.org/10.1080/00220670209596607

Solomon, G. (2007). An examination of entrepreneurship education in the united states. Journal of Small Business and Enterprise Development, 14, 168-182.

Stewart, C. J., \& Cash, W. B. (1985). Interviewing: Principles and practies. Boston, MA: McGrawHill.

Wang, X. (2013). Why students choose STEM majors: Motivation, high school learning, and postsecondary context of support. American Educational Research Journal, 5O(5), 10811121. https://doi.org/10.3102/0002831213488622

Warren, A.K. (1992). Biography and autobiography in the teaching of history and social studies. Retrieved October 20, 2018 from

http://www.historians.org/perspectives/issues/1992/9201/9201TEC.cfm

White, R. T. (1993). Learning science. Oxford: Blackwell Publishers.

Winer, L. R., \& Vazquez-Abad, J. (1995). The potential of repertory grid technique in the assessment of conceptual change in physics. Journal of Constructivist Psychology, 10(4), 363-386. https://doi.org/10.1080/10720539708404632

Yıldırım, A., \& Şimşek, H. (2008). Qualitative research methods in the social sciences. (6th Edition). Ankara: Seçkin Publishing.

Yılmaz, Ö., Yalvaç B., \& Tekkaya C. (1998). Measuring the achievement in and attitudes towards science courses. Education and Science Journal, 22(110), 45-50.

Zak, P. L. (2014). Why your brain loves good storytelling. Harvard Business Review, 28, 1-5.

Zarnowski, M. (2003). History makers: a questioning approach to reading \& writing biographies.Portsmouth, NH: Heinemann. 